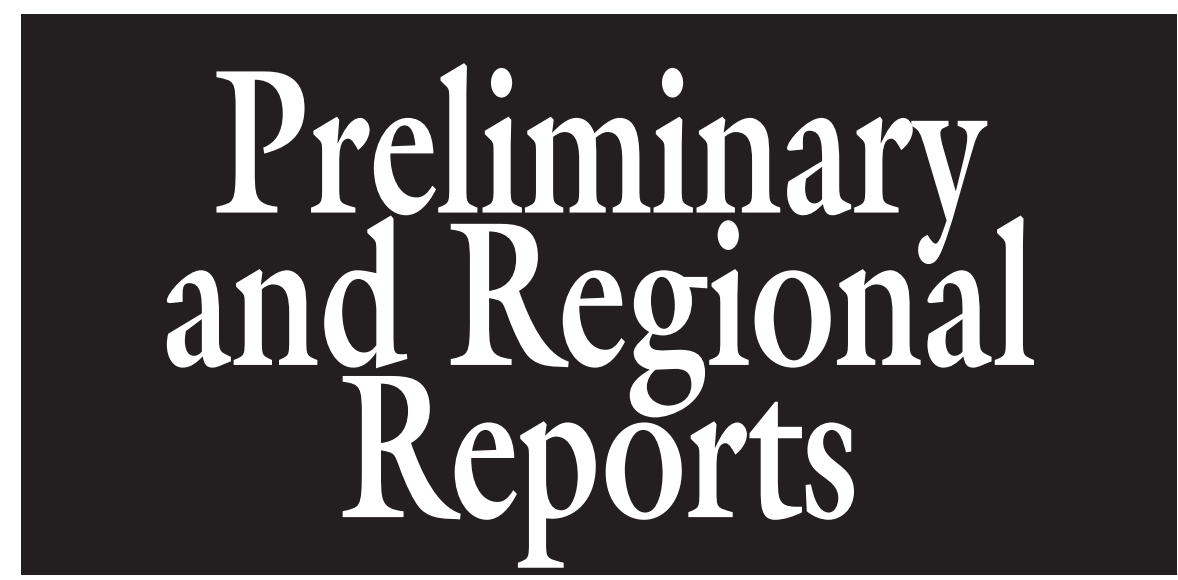

\title{
Yield and Quality of Field-grown Celosia and Globe Amaranth Cut Flowers at Four Plant Densities
}

\author{
Sabine R. Green ${ }^{1,4}$, Geno A. Picchioni ${ }^{1}$, Leigh W. Murray ${ }^{2}$, and \\ Marisa M. Wall ${ }^{3}$
}

AdDitional INDEX wORDs. dried flower specialty crops, Gomphrena globosa, Gomphrena haageana, Celosia spicata, Celosia argentea, small farms

SUMmARY. Field-grown cut and dried flowers could provide a high-value crop selection for New Mexico. We conducted a 1-year field study to evaluate flower yield and quality characteristics of common globe amaranth (Gomphrena globosa), 'Strawberry Fields' globe amaranth (Gomphrena haageana), cockscomb celosia (Celosia argentea var. cristata 'Chief Mix'), and wheat celosia (Celosia spicata' Pink Candle'). Within-row spacing of 15 or $20 \mathrm{~cm}$ combined with two-row or three-row per bed plantings resulted in field planting densities ranging from 66,670 to 120,010 plants / ha of common globe amaranth and 'Strawberry Fields' globe amaranth, and 100,005 to 200,010 plants/ha of cockscomb and wheat celosia. All but cockscomb celosia produced four harvests that began 22 May and ended 18 Oct., depending on species. Both globe amaranth species had a 5- to 6-month harvest season, two to three midseason to late-season peak harvests, and over 1000 harvested stems totaling 1.4 to $1.8 \mathrm{~kg}$ dry weight per $1.5-\mathrm{m}^{2}$ plot across the season. Both celosia species had a 4.5-month harvest season, one early summer peak harvest, and fewer than 300 harvested stems totaling 0.6 to $0.7 \mathrm{~kg}$ dry weight per plot for the year. Seasonally progressive increases in flowering stem length of both globe amaranth species and wheat celosia, and in flowering stem diameter of both globe amaranth species and cockscomb celosia, were observed. Flowering head size of both globe amaranth species and of wheat celosia varied little with harvest season, whereas the head diameter of cockscomb celosia increased with the season. Postharvest flower retention after mechanical impact was about $2 \%$ higher for common globe amaranth than it was for 'Strawberry Fields' globe amaranth, decreased by about $6 \%$ from early to later harvests for both celosia species, and was inversely related to the head size of both globe amaranth species and cockscomb celosia. Despite the wide range in planting density, the density effect was largely limited to cockscomb celosia. For that species, three-row planting (high density) increased the total number of spray flower (multiple head) stems, provided longer stems later into the season and wider heads midway into the season, and prolonged the production of spray stems $(15-\mathrm{cm}$ spacing only). Results demonstrate that these four species are excellent candidates as new specialty crops in semiarid conditions.

S pecialty cut flowers have become important to the United States floriculture industry. The semiarid southwestern United States, including southern New Mexico, has limited availability of specialty cut dried flowers ("everlasting" flowers), but the regional climate, with a relatively long growing season, high light intensity, and low relative humidity, is conducive to field production and processing of dried flowers (Stevens, 1998). Successful introduction of specialty cut dried flowers could increase agricultural diversification and the number of water use options for high-value crops in struggling rural economies of $\mathrm{New}$ Mexico.

Globe amaranth and celosia bloom prolifically and are recognized in the literature as specialty cut flowers. Celosia thrives in warm weather (Dole and Wilkins, 2005), and common globe amaranth is classified as heat tolerant (Still, 1994). Also, several cultivars of common globe amaranth and cockscomb celosia withstand high levels of root zone salinity (Carter et al., 2005; JongGoo and van Iersel, 2002). Thus, these species have good potential as dried flowers in hot, dry, southern New Mexico, the soils of which are frequently affected by high salinity.

We found no scientific data on yield and flower stem quality of fieldgrown globe amaranth and celosia as affected by species and cultivar selection, planting density, and harvest timing. Growth rates and productivity of these warm-season annuals under adequate irrigation should increase with the progression of a hot growing season, but the timing, frequency, and amounts of multiple harvests need to be determined. Increasing the number of rows per bed or decreasing the distance between plants on a bed result in more plants per land area, but the effects on yield and quality are not adequately known.

In view of the lack of available field data on celosia and globe amaranth, the first objective of this study was to make general observations on adaptability of two species of globe amaranth and two species of celosia to southern New Mexico climate and soil under drip-irrigated field conditions. Our second objective was to determine flower stem yield and quality, and postharvest flower retention as affected by species, planting density, and time of harvest.

\section{Materials and methods}

PLANT PROPAGATION AND HARDENING, FIELD STUDY LAYOUT, AND FIELD CULTIVATION. Two species each of globe amaranth and celosia were grown in 2000 as summer annual crops at the Fabian Garcia Science Center on the New Mexico State 
University campus in Las Cruces. The species included common globe amaranth (unspecified proprietary mix), 'Strawberry Fields' globe amaranth, 'Chief Mix' cockscomb celosia, and 'Pink Candle' wheat celosia. Botanically, the relatively small, globular globe amaranth inflorescence is a head. The celosia inflorescence is botanically a spike, or colloquially, a crested "head"-like structure for cockscomb celosia, and a long and narrow "wheat"-like structure for wheat celosia. For simplicity, we hereafter refer to the showy flowering portions of both genera as "heads." The source of all seeds was Park Seed Co. (Greenwood, $\mathrm{SC}$ ).

On 28 Feb. 2000, seeds were sown individually into trays with unit cell volume of $166 \mathrm{~mL}$ (\#606; T.O. Plastics, Clearwater, MN). Cells had been prefilled with $35 \%$ to $55 \%$ sphagnum moss, $30 \%$ to $40 \%$ medium horticultural vermiculite, $10 \%$ to $20 \%$ processed bark ash, and $1 \%$ to $15 \%$ pine bark, by volume (Metromix 360; Scotts, Marysville, $\mathrm{OH}$ ). Trays were placed in a greenhouse with average minimum and maximum air temperatures of 18 and $29^{\circ} \mathrm{C}$, respectively, and maximum midday photosynthetic photon flux (PPF) of $620 \mu \mathrm{mol} \cdot \mathrm{m}^{-2} \cdot \mathrm{s}^{-1}$ as measured by a quantum meter (model QMSS; Apogee Instruments, Logan, UT).

Seedling emergence occurred by 7 Mar. On 21 Mar., seedlings were fertilized with a topdressing of $14 \mathrm{~N}-$ $6.2 \mathrm{P}-11.6 \mathrm{~K}$ slow-release fertilizer (Osmocote, Scotts) at $\approx 0.14 \mathrm{oz} / \mathrm{ft}^{2}$ tray surface area. Seedlings were handwatered as necessary in the greenhouse until 27 Mar. (about 3 weeks after emergence), at which time they were moved to a lath house for 2 weeks to harden and await field transplanting. In the lath house, the average daily temperature range was 3 to $31^{\circ} \mathrm{C}$ and

This work was supported by the New Mexico Agricultural Experiment Station.

The mention of a trademark, proprietary product, or vendor does not constitute an endorsement by New Mexico State University to the exclusion of other products or vendors that may also be suitable.

${ }^{1}$ Department of Plant and Environmental Sciences, New Mexico State University, Las Cruces, NM 88003

${ }^{2}$ Department of Statistics, Kansas State University, Manhattan, KS 66506

${ }^{3}$ U.S. Department of Agriculture, Agricultural Research Service, U.S. Pacific Basin Agricultural Research Center, P.O. Box 4459, Hilo, HI 96720-0459

${ }^{4}$ Corresponding author. E-mail: swhitley@nmsu.edu. the maximum PPF was 1050 $\mu \mathrm{mol} \cdot \mathrm{m}^{-2} \cdot \mathrm{s}^{-1}$.

The soil of the experimental field site was a Glendale fine-silty, mixed (calcareous), thermic, Typic torrifluvent. A preliminary composite soil sample combining five, 1 -inch-wide $x$ 12 -inch-long cores uniformly distributed across the site was taken to assess soil nitrate-nitrogen $\left(\mathrm{NO}_{3}-\mathrm{N}\right)$, organic matter, available phosphorus $(\mathrm{P})$, soluble potassium $(\mathrm{K})$, electrical conductivity $\left(\mathrm{EC}_{\mathrm{e}}\right)$, and $\mathrm{pH}$. Nitrate$\mathrm{N}$ (1:5 soil:water extract) and organic matter were determined by the methods of Gavlak et al. (1994), while extraction and analysis for $\mathrm{P}, \mathrm{K}, \mathrm{EC}_{\mathrm{e}}$, and $\mathrm{pH}$ were by methods reported by Picchioni et al. (2004). The composite sample of the top 12 inches contained $25 \mathrm{mg} \cdot \mathrm{kg}^{-1} \mathrm{NO}_{3}-\mathrm{N}, 1 \%$ organic matter, $15 \mathrm{mg} \cdot \mathrm{kg}^{-1}$ available $\mathrm{P}, 46 \mathrm{mg} \cdot \mathrm{kg}^{-1}$ soluble $\mathrm{K}$, an $\mathrm{EC}_{\mathrm{e}}$ of $2.5 \mathrm{dS} \cdot \mathrm{m}^{-1}$, and a $\mathrm{pH}$ of 7.4. Before field transplanting, the field received a surface broadcast application of $\mathrm{P}$ at $68 \mathrm{~kg} \cdot \mathrm{ha}^{-1}$ as $0 \mathrm{~N}-$ 20.5P-0K (Helena Chemical, Collierville, $\mathrm{TN}$ ). A subsurface drip irrigation system was installed as a single line of T-tape (model 508-08-670; TSystems, San Diego, CA) buried $10 \mathrm{~cm}$ below the soil surface at the center of raised beds that are described below. The T-tape had a wall thickness of $0.2 \mathrm{~mm}$, single emitters spaced 8 inches apart, and a design flow rate of $0.67 \mathrm{gal} / \mathrm{h}$ per $100 \mathrm{ft}$.

Four transplanting densities were selected for both globe amaranth species and both celosia species, totaling 16 density by species treatments (Table 1). Park Seed Co. recommended that spacings were used for the $30-\mathrm{cm}$ in-row spacing for globe amaranth and for the $20-\mathrm{cm}$ in-row spacing for the celosia species. The three-row per bed design was staggered as a matrix planting so that no plants would be separated by less than the in-row spacing. A denser planting arrangement than commercially recommended was included by reducing the in-row spacing by $5 \mathrm{~cm}$ (e.g., $25-\mathrm{cm}$ in-row treatments for globe amaranth species, $15-\mathrm{cm}$ in-row treatments for celosia species).

The 16 treatments were arranged in a randomized complete block design with four blocks. The total study area, including buffer area, measured $6.1 \mathrm{~m}$ wide by $45.7 \mathrm{~m}$ long ( $0.03 \mathrm{ha}$ total). For a given species $\times$ density treatment, each single-row experimental unit (plot) measured $1.0 \mathrm{~m}$ wide by $2.4 \mathrm{~m}$ long $\left(2.4 \mathrm{~m}^{2}\right)$. Stems were harvested (as described below) from the inner $1.5 \mathrm{~m}$ of the plot length (63\% of plot area), leaving a buffer zone of $0.45 \mathrm{~m}$ at both ends. Thus, the total harvested plot area was $1.5 \mathrm{~m}^{2}$.

Seedlings were transplanted in the field on 11 Apr. on standard raised beds measuring $61 \mathrm{~cm}$ wide and spaced $1 \mathrm{~m}$ apart, and were grown until a final harvest on 18 Oct. During the 190-d field cultivation, the minimum and maximum air temperature extremes were 2 and $39^{\circ} \mathrm{C}$, respectively, the maximum $P P F$ exceeded $2000 \mu \mathrm{mol} \cdot \mathrm{m}^{-2} \cdot \mathrm{s}^{-1}$ (maximum range on quantum meter), and a total of 4.7 inches of rain fell (3.5 inches from 17 to 29 June). Weeds were controlled by hand cultivation within beds and by mechanical cultivation between beds.

Throughout the study, drip irrigation was supplied to prevent the soil matric potential from decreasing below -20 cbar at a 9-inch depth as monitored throughout each week using

\begin{tabular}{llll}
\hline $\begin{array}{l}\text { Units } \\
\begin{array}{l}\text { To convert U.S. to SI, } \\
\text { multiply by }\end{array}\end{array}$ & U.S. unit & SI unit & $\begin{array}{l}\text { To convert SI to U.S., } \\
\text { multiply by }\end{array}$ \\
\hline 0.4047 & $\mathrm{acre}(\mathrm{s})$ & $\mathrm{ha}$ & 2.4711 \\
1 & $\mathrm{cbar}$ & $\mathrm{kPa}$ & 1 \\
29.5735 & $\mathrm{fl} \mathrm{oz}$ & $\mathrm{mL}$ & 0.0338 \\
0.3048 & $\mathrm{ft}$ & $\mathrm{m}$ & 3.2808 \\
0.0929 & $\mathrm{ft}^{2}$ & $\mathrm{~m}^{2}$ & 10.7639 \\
3.7854 & $\mathrm{gal}$ & $\mathrm{L}$ & 0.2642 \\
2.54 & inch(es) & $\mathrm{cm}$ & 0.3937 \\
25.4 & inch $(\mathrm{es})$ & $\mathrm{mm}$ & 0.0394 \\
0.4536 & $\mathrm{lb}$ & $\mathrm{kg}$ & 2.2046 \\
1.1209 & $\mathrm{lb} / \mathrm{acre}$ & $\mathrm{kg} \cdot \mathrm{ha}^{-1}$ & 0.8922 \\
1 & $\mathrm{mmho} / \mathrm{cm}$ & $\mathrm{dS} \cdot \mathrm{m}^{-1}$ & 1 \\
28.3495 & $\mathrm{oz}$ & $\mathrm{g}$ & 0.0353 \\
305.1517 & $\mathrm{oz} / \mathrm{ft}^{2}$ & $\mathrm{~g} \cdot \mathrm{m}^{-2}$ & 0.0033 \\
1 & $\mathrm{ppm}$ & $\mathrm{mg} \cdot \mathrm{kg}^{-1}$ & 1 \\
0.9072 & ton $(\mathrm{s})$ & $\mathrm{Mg}$ & 1.1023 \\
$\left({ }^{\circ} \mathrm{F}-32\right) \div 1.8$ & ${ }^{\circ} \mathrm{F}$ & ${ }^{\circ} \mathrm{C}$ & $\left(1.8 \times{ }^{\circ} \mathrm{C}\right)+32$ \\
& & &
\end{tabular}


Table 1. Plant densities for common globe amaranth, 'Strawberry Fields' globe amaranth, cockscomb celosia, and wheat celosia.

\begin{tabular}{|c|c|c|c|c|c|}
\hline Species & $\begin{array}{c}\text { Density } \\
\text { treatment code }\end{array}$ & $\begin{array}{l}\text { Rows per } \\
\text { bed (no.) }\end{array}$ & $\begin{array}{l}\text { Within-row } \\
\text { spacing }(\mathrm{cm})^{\mathrm{z}}\end{array}$ & $\begin{array}{c}\text { Plants per } 1.5-\mathrm{m}^{2} \\
\left(16.15 \mathrm{ft}^{2}\right) \text { harvested } \\
\text { plot }(\text { no. })^{\mathrm{x}}\end{array}$ & $\begin{array}{c}\text { Density (plants } \\
\text { per hectare) }^{w}\end{array}$ \\
\hline Common and 'Strawberry & $2-30$ & 2 & 30 & 10 & 66,670 \\
\hline \multirow{2}{*}{ Fields' globe amaranth } & $3-30$ & 3 & 30 & 15 & 100,005 \\
\hline & $3-25$ & 3 & 25 & 18 & 120,006 \\
\hline \multirow{2}{*}{ celosia } & $3-20$ & 3 & 20 & 23 & 153,341 \\
\hline & $3-15$ & 3 & 15 & 30 & 200,010 \\
\hline
\end{tabular}

${ }^{\mathrm{z}}$ First number refers to number of rows per bed; second number referring to within-row spacing in centimeters; $1 \mathrm{~cm}=0.3937 \mathrm{inch}$.

${ }^{\mathrm{y}} 1$ plant $/ 1.5 \mathrm{~m}^{2}=0.0619$ plant $/ \mathrm{ft}^{2}$.

${ }^{\mathrm{x}} \mathrm{l}$ plant $/ \mathrm{ha}=0.4047$ plant $/$ acre.

two tensiometers positioned within the planted area (model R; Irrometer, Riverside, CA). A daily irrigation duration averaged $3 \mathrm{~h}$ in April and May, and $4 \mathrm{~h}$ in June and thereafter. The total amount of irrigation supplied for the 190-d field cultivation was $157 \mathrm{~cm}$, which was $113 \%$ of the $139 \mathrm{~cm}$ total evapotranspiration for the tall reference crop of alfalfa (Medicago sativa) during the same year and dates, recorded and archived under a New Mexico Climate Center automated weather station located within $200 \mathrm{~m}$ of the test plots (New Mexico State University, 2009). Water-soluble fertilizer (26N0P-0K; Helena Chemical) was supplied through the irrigation water. Five fertilizer applications were made between $27 \mathrm{Apr}$. and $15 \mathrm{June}$ ( $45 \mathrm{~kg} \cdot \mathrm{ha}^{-1}$ $\mathrm{N}$ total), four applications in July (103 $\mathrm{kg} \cdot \mathrm{ha}^{-1} \mathrm{~N}$ total), and a final application in September $\left(7 \mathrm{~kg} \cdot \mathrm{ha}^{-1} \mathrm{~N}\right)$. The total annual $\mathrm{N}$ application was $155 \mathrm{~kg} \cdot \mathrm{ha}^{-1}$.

FLOWER STEM HARVESTS, FRESH YIELD MEASUREMENTS, AND DRYING. Flower stems were harvested by cutting 6 inches from the top of the raised beds and at full bloom, after visual assessment of the crop following maturity indices for dried flowers in Armitage (1993). For both globe amaranth species, harvest time was determined by attainment of an acceptable length of flower stem and by visual assessment of $\approx 75 \%$ of full mature color of the field rows without over-mature fading. Determination of cockscomb celosia harvest dates was aided by the appearance of small black seeds on the undersides of the flower heads, while harvest dates of wheat celosia coincided with a deep pink coloration at the tip of the head. Common globe amaranth and cockscomb celosia produced three and five different flower colors, respectively, which were separated for postharvest color analysis (not reported here). All but cockscomb celosia provided four harvests, with harvest date and days after transplanting (DAT) as follows: common globe amaranth on 30 May, 5 July, 7 Aug., and 19 Sept. $(49,85,118$, and 161 DAT); 'Strawberry Fields' globe amaranth on 16 June, 6 July, 21 Aug., and 18 Oct. $(66,86,132$, and 190 DAT); cockscomb celosia on 8 June, 11 July, and 28 Aug. (58, 91, and 139 DAT); and wheat celosia on 22 May, 20 June, 17 July, and 26 Aug. (41, 70, 97, and 137 DAT). The number of seasonal postharvest observations was 48 for cockscomb celosia (three harvests $\times$ four densities $\times$ four replications), and for all other species, 64 (four harvests $\times$ four densities $\times$ four replications).

On all dates listed above, flower stems were hand-harvested before noon using a sterilized cutting tool. Repeated harvests were made until production declined to less than $\approx 1 / 3$ the color at peak harvest. All species produced flower stems of two types: those that supported one head (single-flower stems) and those that supported two or more heads (spray flower stems.) Flower stem yield data at harvest combined the single-flower and spray flower stems for fresh weight, length, and total stem number, with individual counts for single-flower and spray flower stems. Stem fresh weights and numbers were determined for the entire harvested plot area, while a random subsample of 10 stems from the harvested portion of the plot (mixed single-flower and spray flower stems representative of the plot) was used to determine average stem length.
All of the fresh stems harvested from the plot were tied into 10 -stem single-color bunches to dry. The fresh bunches were hung upside-down inside a dark, ventilated storage shed and were monitored daily until tissues were brittle to the touch, which took 4 to $14 \mathrm{~d}$, depending on species and weather conditions. Total flower stem dry weights (combined single-flower and spray flower stems) were obtained by weighing the dried bunches, which were then placed in ventilated boxes and kept in the shed to await further observations.

Determination OF DRIED STEM DIAMETER, FLOWERING HEAD SIZE, AND FLOWER RETENTION ON IMPACT. For these postharvest responses, we did not separate single and spray stems. Subsample measurements were averaged over bunches to obtain a per-plot mean.

Stem diameter was recorded and data were combined after 8 weeks of dry storage by using a digital handheld caliper. Diameter was measured twice, in opposite equatorial dimensions, and immediately below the non-flowering portion of the stem on three randomly selected stems from three randomly selected bunches per treatment plot $(\mathrm{n}=$ three per plot $)$.

The size of the dried flower heads (combined single-flower and spray flower stems) was also determined after 8 weeks of dry storage using the caliper on three randomly selected flower heads per treatment plot $(\mathrm{n}=$ three per plot $)$ after selecting bunches and stems as described above for stem diameter. For both globe amaranth species, head size was determined as the average of the two maximum flowering head distances, 
one along the vertical axis and the other along the horizontal axis of the head. For the crested flower head of cockscomb celosia, the head diameter was averaged among two measurements along opposite equatorial axes at maximum diameter by viewing in a downward direction from above the apical surface. Length of the long and narrow wheat celosia head was determined by a single measurement. After head size measurements, stem bunches were returned to their boxes.

To evaluate flower retention of combined single-flower and spray flower stems after 8 weeks of dry storage, all dried bunches were subjected to mechanical impact. The data were pooled over bunch and color to obtain a plot mean. Flower shattering was induced twice by dropping the individual dried bunches from a $1-m$ height onto a tile floor and recording loss in bunch dry matter. The first drop (side drop) was made with the bunch oriented horizontally and the second drop (end drop) was made immediately thereafter with the bunch oriented vertically and flowering head facing downward. The bunch dry weight obtained after each of the drops was compared with the original (harvest) bunch dry weight before shattering to determine the percentage of flower retention by the bunch (e.g., bunch dry weight after drop $\div$ bunch dry weight at harvest $\times 100$ ).

EXPERIMENTAL DESIGN AND Statistical analysis. Due to dissimilarities in growth and flowering characteristics, separate statistical analyses were performed for the two celosia species. We also avoided statistical comparisons between the globe amaranth species and the celosia species due to the different plant densities and inherent differences in flower morphology. However, we statistically compared common and 'Strawberry Fields' globe amaranth because both species have similar plant architecture and bloom structure.

Harvest data for flower stem fresh weight, dry weight, average length, and the numbers of single-flower stems, spray flower stems, and total stems per harvest were subjected to analysis of variance using the MIXED procedure of SAS (version 8; SAS Institute, Cary, NC). For celosia, these data were analyzed separately for the two species as a split-plot in time in a randomized complete block design with density as the whole-plot treatment factor and harvest date as the split-plot factor. Data for both globe amaranth species were pooled in a single analysis and the data were analyzed as a split-plot in a randomized complete block design with the whole plot treatments in a two (species) by four (density) factorial and with harvest date as the split-plot factor.

For the variables calculated over the growing season- total stem weight and number yields, and overall average stem length-data were analyzed by the GLM procedure of SAS. Celosia data were analyzed separately for the two species as a randomized complete block design with density as the treatment factor. Analogous data for both globe amaranth species were again pooled for comparison and were analyzed as a two (species) $\times$ four (density) factorial in a randomized complete block design. Data for flower stem diameter, flower head size, and flower retention on impact were analyzed as described above for per-harvest data for all four species. When the $F$-test for a main effect was significant, the relevant treatment means were separated using pairwise comparisons by least significant difference at $P \leq 0.05$.

\section{Results and discussion}

Flower STEM FRESH WEIGHT, DRY WEIGHT, LENGTH, AND NUMBERS PRODUCED. Four common globe amaranth harvests began about 2 weeks earlier and were more evenly spaced (33-43 d apart) than those of the four 'Strawberry Fields' globe amaranth harvests [20-58 d apart (Table 2)]. In addition, common globe amaranth produced mostly spray flower stems (especially after the first harvest), whereas 'Strawberry Fields' globe amaranth produced mostly single-flower stems throughout the year (Tables 2 and 3 ). Neither transplanting density nor density $\times$ harvest interaction affected flower stem fresh or dry yield, stem length, or stem numbers of common or 'Strawberry Fields' globe amaranth (data not shown), suggesting that any density higher than the lowest density used in the study (Table 1 ) would not be cost-effective for stem

Table 2. Harvest date means for common and 'Strawberry Fields' globe amaranth yield components averaged across planting densities on a $1.5-\mathrm{m}^{2}\left(16.15 \mathrm{ft}^{2}\right)$ plot.

\begin{tabular}{|c|c|c|c|c|c|c|c|}
\hline Species & $\begin{array}{c}\text { Harvest } \\
\text { date }^{z}\end{array}$ & $\begin{array}{l}\text { Total flower stem } \\
\text { fresh wt }(\mathrm{kg})^{\mathrm{y}}\end{array}$ & $\begin{array}{l}\text { Total flower stem } \\
\text { dry wt (kg) }\end{array}$ & $\begin{array}{l}\text { Flower stem } \\
\text { length }(\mathrm{cm})^{\mathrm{y}}\end{array}$ & $\begin{array}{l}\text { Single-flower } \\
\text { stems (no.) }\end{array}$ & $\begin{array}{l}\text { Spray flower } \\
\text { stems (no.) }\end{array}$ & $\begin{array}{l}\text { Total flower } \\
\text { stems (no.) }^{\mathrm{x}}\end{array}$ \\
\hline \multirow{4}{*}{$\begin{array}{l}\text { Common globe } \\
\text { amaranth }\end{array}$} & 30 May & $0.38 b^{w}$ & $0.03 \mathrm{~b}$ & $20.9 c$ & $79 \mathrm{~b}$ & $64 c$ & $144 \mathrm{c}$ \\
\hline & 5 July & $3.98 \mathrm{a}$ & $0.62 \mathrm{a}$ & $41.5 \mathrm{~b}$ & $68 \mathrm{~b}$ & $304 \mathrm{~b}$ & $373 \mathrm{~b}$ \\
\hline & 19 Sept. & $3.69 \mathrm{a}$ & $0.58 \mathrm{a}$ & $46.0 \mathrm{a}$ & $103 \mathrm{a}$ & $342 \mathrm{a}$ & $445 \mathrm{a}$ \\
\hline & $P$ value & $<0.0001$ & $<0.0001$ & $<0.0001$ & 0.0010 & $<0.0001$ & $<0.0001$ \\
\hline globe amaranth & 6 July & $2.39 \mathrm{a}$ & $0.46 \mathrm{a}$ & $42.9 \mathrm{a}$ & $306 a$ & $65 \mathrm{~b}$ & $371 \mathrm{a}$ \\
\hline & 21 Aug. & $2.35 \mathrm{a}$ & $0.54 \mathrm{a}$ & $47.1 \mathrm{a}$ & $285 \mathrm{a}$ & $86 \mathrm{a}$ & $371 \mathrm{a}$ \\
\hline & 18 Oct. & $0.87 \mathrm{~b}$ & $0.20 \mathrm{~b}$ & $31.8 \mathrm{~b}$ & $216 \mathrm{~b}$ & $45 \mathrm{c}$ & $260 \mathrm{~b}$ \\
\hline & $P$ value & $<0.0001$ & $<0.0001$ & $<0.0001$ & 0.0128 & $<0.0001$ & $<0.0001$ \\
\hline & SE & 0.17 & 0.04 & 1.0 & 27 & 7 & 30 \\
\hline
\end{tabular}

${ }^{2}$ Common globe amaranth chronological harvest dates correspond to 49, 85, 118, and 161 d after transplant (DAT), respectively; 'Strawberry Fields' globe amaranth chronological harvest dates correspond to $66,86,132$, and 190 DAT, respectively.

y $1 \mathrm{~kg}=2.2046 \mathrm{lb}, 1 \mathrm{~cm}=0.3937$ inch.

${ }^{x}$ Total $=$ single-flower + spray stems.

"Pairwise comparisons within columns and species by least significant difference at $\alpha=0.05$; means that have the same letter are not significantly different.

${ }^{\mathrm{S} S E}$ differed within response variable due to unbalanced data; the maximum SE is reported. 
Table 3. Means for common and 'Strawberry Fields' globe amaranth yield components recorded on a $1.5-\mathrm{m}^{2}\left(16.15 \mathrm{ft}^{2}\right)$ plot throughout four harvests and at four planting densities.

\begin{tabular}{|c|c|c|c|c|}
\hline Species & $\begin{array}{l}\text { Cumulative flower } \\
\text { stem fresh wt }(\mathrm{kg})^{\mathrm{z}}\end{array}$ & $\begin{array}{l}\text { Cumulative flower } \\
\text { stem dry wt (kg) }\end{array}$ & $\begin{array}{c}\text { Cumulative single-flower } \\
\text { stems (no.) }\end{array}$ & $\begin{array}{l}\text { Cumulative spray } \\
\text { flower stems (no.) }\end{array}$ \\
\hline Common globe amaranth & 11.74 & 1.76 & 350 & 982 \\
\hline $\begin{array}{l}\text { 'Strawberry Fields' } \\
\text { globe amaranth }\end{array}$ & 6.20 & 1.35 & 1007 & 196 \\
\hline$P$ value & $<0.0001$ & 0.0062 & $<0.0001$ & $<0.0001$ \\
\hline $\mathrm{SE}^{\mathrm{y}}$ & 0.36 & 0.09 & 45 & 35 \\
\hline
\end{tabular}

${ }^{\mathrm{z}} 1 \mathrm{~kg}=2.2046 \mathrm{lb}$

${ }^{y_{S E}}$ differed within response variable due to unbalanced data; the maximum SE is reported.

yield and length under these conditions. For both globe amaranth species, harvested stem yields in weight and number, and average stem length varied with harvest date $(P \leq 0.0128)$, but the seasonal patterns differed between these species (Table 2). After a limited initial yield for common globe amaranth (30 May), high yields, long stems, and large numbers of stems persisted throughout the three early to late summer harvests ( 5 July19 Sept.). By contrast, there were only two major harvests for 'Strawberry Fields' globe amaranth (early to late summer harvest dates of 6 July and 21 Aug.). The last 'Strawberry Fields' globe amaranth harvest in early fall (18 Oct.) provided relatively low weight yield, short stems, and fewer stems, and it required about 1 month longer to obtain than the fourth and final common globe amaranth harvest.

The seasonal cumulative dry weight yield per plot was $30 \%$ higher for common globe amaranth than for 'Strawberry Fields' globe amaranth, and the cumulative fresh weight yield per plot for common globe amaranth was $89 \%$ higher than it was for 'Strawberry Fields' globe amaranth (Table 3 ). The latter, wider margin of difference was associated with a higher water content of common globe amaranth stems compared with 'Strawberry Fields' globe amaranth stems $(85 \%$ vs. $78 \%$, respectively). For common globe amaranth and 'Strawberry Fields' globe amaranth, average seasonal stem length (38 and $37 \mathrm{~cm}$, respectively) and $\mathrm{cu}^{-}$ mulative stem number (1333 and 1202 stems, respectively) did not differ significantly. The average dry weight per stem was also similar for both species (1.3 and $1.1 \mathrm{~g}$ per stem for common globe amaranth and 'Strawberry Fields' globe amaranth, respectively).

The initial harvests began about 2 weeks earlier for wheat celosia than for cockscomb celosia, and wheat celosia provided four harvests compared with three harvests for cockscomb celosia. Porat et al. (1995) reported that flowering of cockscomb celosia (C. argentea var. plumosa) is delayed under long photoperiods $(>16 \mathrm{~h})$. Thus, the facultative shortday flowering requirement for cockscomb celosia (Dole and Wilkins, 2005) may have limited summer flower initiation, and thus summer harvesting of this species in our study. Wheat celosia yielded about twice the total number of stems than cockscomb celosia. However, the total fresh and dry stem weight yields were similar for these species (Table 4), because the individual cockscomb celosia stems were about twice as heavy as those of wheat celosia (4.0 vs. $2.3 \mathrm{~g}$ dry weight per stem, respectively).

Of the total cockscomb celosia stems reported in Table 4, 67\% were single-flower stems, whereas wheat celosia stems were about evenly divided between single-flower and spray stems when totaled across the year. For both celosia species, the stem fresh weight and dry weight yields, numbers of single-flower stems, and total numbers of stems were affected by the harvest date (Table 4). Peak production for both celosia species was in early summer (20 June-17 July). For cockscomb celosia, the total number of stems and number of single-flower stems were highest at the 11 July harvest. For wheat celosia, there were two peak harvests (20 June and 17 July) for total numbers of stems and singleflower stems, and one harvest peak of 17 July for number of spray flower stems, at which time all of the harvested stems (single-flower and spray flower stems combined) had attained their maximum length of the season.

Unlike common and 'Strawberry Fields' globe amaranth, planting density affected stem numbers of the two celosia species (data not shown). With three-row plantings, cockscomb celosia plots produced a seasonal average of 37 single-flower stems, whereas the two-row plots provided only 25 single-flower stems $(P=$ 0.0041 ), leading to a parallel difference in total number of stems across the year ( 57 stems per plot for threerow, 38 stems per plot for two-row; $P$ $=0.0015)$. In wheat celosia plots, the three-row plantings provided a seasonal average of 46 single-flower stems, whereas the two-row plantings provided only 34 single-flower stems $(P=0.0096)$, although total stem number was unaffected by density treatment.

For cockscomb celosia, the harvest $x$ density interaction affected the average flower stem length $(P=$ 0.0035 ) and the number of harvested spray flower stems throughout the season $(P=0.0200)$. At the third and final harvest of 28 Aug., cockscomb celosia stem length had become density-dependent, as the three-row plantings provided stems that averaged about $10 \mathrm{~cm}$ longer than those on the two-row plantings. This is consistent with the concept that closer spacings of cockscomb celosia encourage longer flowering stems (Dole and Wilkins, 2005). Also, by the final harvest, the number of cockscomb celosia spray flower stems remained relatively unchanged at the highest density (three-row bed with $15-\mathrm{cm}$ in-row spacing), whereas there were sharp declines in spray production with the other plantings.

Although we did not statistically compare the two globe amaranth species with the two celosia species, growers may be interested in general differences between the genera that affect labor hours in cutting, field removal, transport, and processing. Both globe amaranth species had 
Table 4. Harvest date means for cockscomb and wheat celosia yield components averaged across planting densities on a $1.5-\mathrm{m}^{2}\left(16.15 \mathrm{ft}^{2}\right)$ plot.

\begin{tabular}{|c|c|c|c|c|c|c|c|}
\hline Species & $\begin{array}{c}\text { Harvest } \\
\text { date }^{\mathrm{z}}\end{array}$ & $\begin{array}{l}\text { Total flower stem } \\
\text { fresh wt }(\mathrm{kg})^{\mathrm{y}}\end{array}$ & $\begin{array}{l}\text { Total flower stem } \\
\text { dry wt (kg) }\end{array}$ & $\begin{array}{l}\text { Flower stem } \\
\text { length }(\mathrm{cm})^{\mathrm{y}}\end{array}$ & $\begin{array}{l}\text { Single-flower } \\
\text { stems (no.) }\end{array}$ & $\begin{array}{l}\text { Spray flower } \\
\text { stems (no.) }\end{array}$ & $\begin{array}{l}\text { Total flower } \\
\text { stems (no.) }\end{array}$ \\
\hline \multirow{5}{*}{$\begin{array}{l}\text { Cockscomb } \\
\text { celosia }\end{array}$} & 8 June & $0.84 \mathrm{~b}^{\mathrm{w}}$ & $0.12 \mathrm{~b}$ & 25.0 & $36 \mathrm{~b}$ & 19 & $55 \mathrm{~b}$ \\
\hline & 11 July & $2.12 \mathrm{a}$ & $0.33 \mathrm{a}$ & 42.3 & $44 \mathrm{a}$ & 20 & $64 \mathrm{a}$ \\
\hline & 28 Aug. & $0.78 \mathrm{~b}$ & $0.12 \mathrm{~b}$ & 24.5 & $14 \mathrm{c}$ & 9 & $23 \mathrm{c}$ \\
\hline & Total $^{\mathrm{v}}$ & 3.73 & 0.56 & - & 94 & 48 & 142 \\
\hline & $P$ value & $<0.0001$ & $<0.0001$ & - & $<0.0001$ & - & $<0.0001$ \\
\hline \multirow{6}{*}{ Wheat celosia } & 20 June & $1.01 \mathrm{~b}$ & $0.18 \mathrm{~b}$ & $39.2 \mathrm{c}$ & $54 \mathrm{a}$ & $43 \mathrm{~b}$ & $98 \mathrm{a}$ \\
\hline & 17 July & $1.57 \mathrm{a}$ & $0.32 \mathrm{a}$ & $53.1 \mathrm{a}$ & $51 \mathrm{a}$ & $56 \mathrm{a}$ & $108 \mathrm{a}$ \\
\hline & 26 Aug. & $0.78 \mathrm{c}$ & $0.16 \mathrm{~b}$ & $44.2 \mathrm{~b}$ & $30 \mathrm{~b}$ & $41 \mathrm{~b}$ & $60 \mathrm{~b}$ \\
\hline & Total & 3.66 & 0.67 & - & 159 & 140 & 290 \\
\hline & $P$ value & $<0.0001$ & $<0.0001$ & $<0.0001$ & $<0.0001$ & $<0.0001$ & $<0.0001$ \\
\hline & SE & 0.17 & 0.03 & 1.4 & 3 & 7 & 8 \\
\hline
\end{tabular}

${ }^{\mathrm{z}}$ Cockscomb celosia chronological harvest dates correspond to 58, 91, and $139 \mathrm{~d}$ after transplant (DAT), respectively; wheat celosia chronological harvest dates correspond to $41,70,97$, and 137 DAT, respectively.

$y_{1} \mathrm{~kg}=2.2046 \mathrm{lb}, \mathrm{l} \mathrm{cm}=0.3937$ inch.

xTotal $=$ single-flower + spray stems.

"Pairwise comparisons within columns and species by least significant difference at $\alpha=0.05$; means that have the same letter are not significantly different.

"Seasonal (cumulative) totals are shown directly below the final harvest dates.

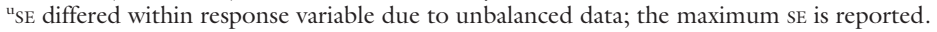

a 5- to 6-month harvest season and both celosia species were about 4.5 months. On a weight basis, both globe amaranth species had two to three peak harvests, while the two celosia species had only one. We harvested nearly six times the number of stems and up to about three times more fresh matter from common and 'Strawberry Fields' globe amaranth than we did for either celosia species. Across the season and on 1 ha, the plot harvest data would equate to 78 $\mathrm{Mg}$ of fresh common globe amaranth stems, $41 \mathrm{Mg}$ of fresh 'Strawberry Fields' globe amaranth stems, and 24 to $25 \mathrm{Mg}$ of fresh cockscomb and wheat celosia stems.

Flower STEM DiAMETER, FLOWERING HEAD SIZE, AND FLOWER RETENTION ON IMPACT. We present the globe amaranth species and celosia species data for flowering stem diameter, head size, and flower retention as pooled across densities. Planting density did not affect these response variables $(P>0.05)$, except for flowering head diameter of cockscomb celosia, as noted below.

Stem diameter averaged across density and harvest was 9\% wider for 'Strawberry Fields' globe amaranth than for common globe amaranth (2.5 vs. $2.3 \mathrm{~mm}$, respectively; $P \leq$ $0.0001)$. There was no species $\times$ density interaction on globe amaranth stem diameter, thus for simplicity, data were pooled across density and species (Table 5 ). The flowering stem diameter of both globe amaranth species and cockscomb celosia tended to increase with progression of the season. The thinnest common and 'Strawberry Fields' globe amaranth stems were produced at the beginning of the season, and thereafter stem diameter increased progressively, up to $29 \%$ by the third harvest date of 7 or 21 Aug. However, between the third and final harvests of 19 Sept. or 18 Oct., there was an $11 \%$ overall reduction in stem diameter averaged across common and 'Strawberry Fields' globe amaranth. The stem diameter of cockscomb celosia increased by $71 \%$ between the first harvest ( 8 June) and last two harvests (11 July and 28 Aug.). Stem diameter of wheat celosia was generally unaffected by the harvest date except at the second harvest (20 June), when it averaged $28 \%$ less than it did at the first, third, and fourth harvests (22 May, 17 July, and 26 Aug. respectively).

Harvest date interacted with density to influence flowering stem diameter averaged across common and 'Strawberry Fields' globe amaranth $(P=0.0460)$. Even though there was a broadly similar pattern for stem diameter in the different densities, there was no increase in stem diameter between the first and second harvests at the 3-30 planting density as there was for the other three plantings. Harvest date also interacted with globe amaranth species in determining stem diameter $(P<0.0001)$.
At the first harvest, stem diameter of common globe amaranth was $42 \%$ less than it was for 'Strawberry Fields' globe amaranth. Thus, early season stems on common globe amaranth might be of limited horticultural importance owing to thin (and presumably weak) stems, and the small yield as reported above. After the first harvest, stem diameter of the two globe amaranth species was markedly similar.

Across harvests and densities, 'Strawberry Fields' globe amaranth flower head size averaged $2.09 \mathrm{~cm}$, while common globe amaranth flower head size averaged $1.77 \mathrm{~cm}(P \leq$ 0.0001 for species main effect). In addition, there was a significant main effect of planting density on the seasonal average flower head diameter of cockscomb celosia $(P=0.0427)$, although pairwise comparisons revealed that the effect involved only two means, $4.28 \mathrm{~cm}$ for the 3-20 planting and $3.67 \mathrm{~cm}$ for the $2-15$ planting. Furthermore, there was no globe amaranth species $\times$ density interaction on head size. For simplicity, flower head size data for globe amaranth were pooled across the two species and four densities; for head size of the two celosia species, data were pooled across the four densities (Table 6).

Wider stem diameters were associated with larger flower head size in both globe amaranth species and cockscomb celosia, but not in wheat celosia. When averaged across both 
Table 5. Means of harvest dates (denoted as sequential harvest number for simplicity) pooled across density on average flower stem diameter (single-flower and spray flower stems combined) of globe amaranth (average of common globe amaranth and 'Strawberry Fields' globe amaranth), cockscomb celosia, and wheat celosia.

\begin{tabular}{lccc}
\hline & \multicolumn{3}{c}{${\text { Avg flower stem diam }(\mathrm{mm})^{\mathrm{z}}}$} \\
\cline { 2 - 4 } Harvest no. $^{\mathrm{y}}$ & Globe amaranth $^{2.1 \mathrm{c}^{\mathrm{x}}}$ & Cockscomb celosia & Wheat celosia \\
\hline 1 & $2.3 \mathrm{~b}$ & $2.6 \mathrm{~b}$ & $3.0 \mathrm{a}$ \\
2 & $2.7 \mathrm{a}$ & $4.6 \mathrm{a}$ & $2.2 \mathrm{~b}$ \\
3 & $2.4 \mathrm{~b}$ & $4.3 \mathrm{a}$ & $3.0 \mathrm{a}$ \\
4 & $<0.0001$ & - & $3.2 \mathrm{a}$ \\
$P$ value & 0.1 & $<0.0001$ & $<0.0001$ \\
$\mathrm{SE}^{\mathrm{w}}$ & & 0.1 & 0.1 \\
\hline
\end{tabular}

${ }^{\mathrm{z}} 1 \mathrm{~mm}=0.0394$ inch

Dates and days after transplant (DAT) for the sequential harvest numbers are listed chronologically as follows: common globe amaranth on 30 May, 5 July, 7 Aug., and 19 Sept. (49, 85, 118 , and 161 DAT, respectively); 'Strawberry Fields' globe amaranth on 16 June, 6 July, 21 Aug., and 18 Oct. (66, 86, 132, and 190 DAT, respectively); cockscomb celosia on 8 June, 11 July, and 28 Aug. (58, 91, and 139 DAT, respectively); and wheat celosia on 22 May, 20 June, 17 July, and 26 Aug. (41, 70, 97, and 137 DAT, respectively).

xPairwise comparisons within columns by least significant difference at $\alpha=0.05$. Means within columns followed by the same letter are not significantly different.

wSE differed within response variable due to unbalanced data; the maximum SE is reported.

Table 6. Means of harvest dates (denoted as sequential harvest number for simplicity) on average flowering head size of globe amaranth (average of common globe amaranth and 'Strawberry Fields' globe amaranth), cockscomb celosia, and wheat celosia. Data represent single-flower and spray flower stems combined and are pooled over density.

\begin{tabular}{lccc}
\hline & \multicolumn{3}{c}{ Flower head size $(\mathrm{cm})^{\mathrm{z}}$} \\
\cline { 2 - 4 } Harvest no. $^{\mathrm{y}}$ & $\begin{array}{c}\text { Globe amaranth } \\
\text { flower head size }\end{array}$ & $\begin{array}{c}\text { Cockscomb celosia } \\
\text { flower head diam }\end{array}$ & $\begin{array}{c}\text { Wheat celosia } \\
\text { flower head length }^{\mathbf{v}}\end{array}$ \\
\hline 1 & $1.89 \mathrm{~b}^{\mathrm{u}}$ & $3.29 \mathrm{c}$ & $10.35 \mathrm{~b}$ \\
2 & $2.07 \mathrm{a}$ & $3.89 \mathrm{~b}$ & $11.46 \mathrm{a}$ \\
3 & $1.88 \mathrm{~b}$ & $4.65 \mathrm{a}$ & $12.25 \mathrm{a}$ \\
4 & $1.85 \mathrm{~b}$ & - & $10.81 \mathrm{ab}$ \\
$P$ value & $<0.0001$ & $<0.0001$ & $<0.0001$ \\
$\mathrm{SE}^{\mathrm{t}}$ & 0.02 & 0.16 & 0.46 \\
\hline
\end{tabular}

${ }^{\mathrm{z}} 1 \mathrm{~cm}=0.3937$ inch

y Dates and days after transplant (DAT) for the sequential harvest numbers are listed chronologically as follows: common globe amaranth on 30 May, 5 July, 7 Aug., and 19 Sept. (49, 85, 118, and 161 DAT, respectively); 'Strawberry Fields' globe amaranth on 16 June, 6 July, 21 Aug., and 18 Oct. $(66,86,132$, and 190 DAT, respectively); cockscomb celosia on 8 June, 11 July, and 28 Aug. (58, 91, and 139 DAT, respectively); and wheat celosia on 22 May, 20 June, 17 July, and 26 Aug. (41, 70, 97, and 137 DAT, respectively).

${ }^{x}$ Average of the two maximum distances along vertical and horizontal axes of flower head.

wAverage of two opposite, equatorial measurements at maximum diameter along horizontal axis of the flower head. 'Single measurement of length of flower head.

"Pairwise comparisons within columns by least significant difference at $\alpha=0.05$. Means followed by the same letter are not significantly different.

${ }^{\mathrm{t}} \mathrm{SE}$ differed within response variable due to unbalanced data; the maximum SE is reported.

globe amaranth species, there was about a $0.3 \mathrm{~cm}$ larger flower head size at the second harvest compared with the other three harvests. That harvest effect resulted from a disproportionately large 'Strawberry Fields' globe amaranth head size relative to common globe amaranth, which led to a species $\times$ harvest interaction $(P=$ 0.0003 ). The average diameter of the relatively large cockscomb celosia flowering heads increased by $41 \%$ from first to last harvest, and in a seasonally progressive manner similar to the stem diameter increase noted above. On the three-row plantings, the head diameter of cockscomb celosia increased by almost $1 \mathrm{~cm}$ between the first and second harvests, while the head diameter on the tworow plantings was largely unchanged during that portion of the season; this contributed to a harvest $x$ density interaction $(P<0.0001)$. For the long wheat celosia heads, there was about a $1 \mathrm{~cm}$ increase in length from first to second harvest, but there was no further increase in head length at subsequent harvests.

Side-dropping the bunches caused an average flower loss of 3\% by the heads (Table 7 ). The ensuing end drop ("head-on" impact) accentuated the losses with, on average, a further $8 \%$ shattering increment. After the side drop, flower retention of the two globe amaranth species did not differ. However, there was a significant species difference in flower retention after the end drop, being $2.4 \%$ higher for common globe amaranth than for 'Strawberry Fields' globe amaranth. Harvest date affected flower retention of both celosia species $(P \leq$ 0.0129 ) in that retention generally declined as the season progressed. Once again, flower retention differences after side dropping - in this case, harvest time-related-became more pronounced after end dropping.

For both globe amaranth species and cockscomb celosia, stem diameter and flower head size (or diameter) were inversely related to retention of flowers on the head. These relationships were less apparent for wheat celosia owing to lack of flower retention data for the first harvest and to the limited variation in head size by harvest means (Table 6). Unknown seasonal variation in our postharvest storage room conditions could also have led to variation in flower retention of the two globe amaranth species and cockscomb celosia. However, there was no relationship between flower retention and seasonal yields in total stem number or dry weight of either globe amaranth species, or between flower retention and by-harvest yields (total stem dry weight and number) for either celosia species.

SignificANCE AND APPLICATION of FINDINGs. There is a need for technical data to determine the adaptability of new specialty crops to semiarid field conditions. In the present study, four species of globe amaranth and celosia produced marketable flower crops in as few as 6 to 9 weeks after transplanting and grew well under the high light intensities, high summer temperatures, dry air, and alkaline soils that are all characteristic of field conditions of the Chihuahuan Desert. Low relative humidity and high summer temperatures made drying easy and essentially energy independent. Alternaria leaf spot (Alternaria alternata) was observed on common globe amaranth in the field during the rainy period of late June, but it did not affect dried flower quality. Otherwise, no insect or disease problems were observed during field production. Therefore, these species are good candidates as specialty flower crops 
Table 7. Means of globe amaranth species and celosia species harvest dates on average flower retention.

\begin{tabular}{|c|c|c|c|}
\hline \multirow[b]{2}{*}{ Species $^{\mathrm{y}}$} & \multicolumn{3}{|c|}{ Flower retention (\% of initial bunch dry wt $)^{\mathrm{z}}$} \\
\hline & Harvest date $^{\mathrm{x}}$ & After side drop & After end drop \\
\hline $\begin{array}{l}\text { Common globe } \\
\text { amaranth }\end{array}$ & - & 96.8 & 88.9 \\
\hline $\begin{array}{c}\text { 'Strawberry Fields' } \\
\text { globe amaranth }\end{array}$ & - & 96.2 & 86.5 \\
\hline$P$ value & & 0.4435 & $<0.0001$ \\
\hline $\mathrm{SE}^{\mathrm{w}}$ & & 0.6 & 0.5 \\
\hline \multirow[t]{3}{*}{ Cockscomb celosia } & 8 June & $98.2 \mathrm{a}^{\mathrm{v}}$ & $91.6 \mathrm{a}$ \\
\hline & 11 July & $96.9 \mathrm{~b}$ & $87.0 \mathrm{~b}$ \\
\hline & 28 Aug. & $95.9 \mathrm{c}$ & $85.8 \mathrm{~b}$ \\
\hline$P$ value & & 0.0004 & $<0.0001$ \\
\hline SE & & 0.4 & 1.1 \\
\hline \multirow[t]{3}{*}{ Wheat celosia } & 20 June & 98.7 a & 94.6 a \\
\hline & 17 July & $96.0 \mathrm{~b}$ & $89.0 \mathrm{~b}$ \\
\hline & 26 Aug. & $96.6 \mathrm{ab}$ & 88.7 b \\
\hline$P$ value & & $<0.0001$ & 0.0129 \\
\hline SE & & 0.3 & 1.8 \\
\hline \multicolumn{4}{|c|}{$\begin{array}{l}{ }^{2} \text { Dry weight retention of dried stem bunches following impact (single-flower and spray flower stems combined). } \\
\text { Retention was assessed following an initial horizontal impact (side drop) and immediately thereafter, following } \\
\text { a second vertical impact (end drop with flower heads facing downward). } \\
\text { yCombined data for the two globe amaranth species were analyzed across the season and densities; separate data for } \\
\text { the two celosia species were analyzed across densities. } \\
\text { 'Cockscomb celosia chronological harvest dates correspond to } 58,91 \text {, and } 139 \mathrm{~d} \text { after transplant (DAT), } \\
\text { respectively; wheat celosia chronological harvest dates correspond to } 70,97 \text {, and } 137 \mathrm{DAT} \text {, respectively. } \\
\text { "se differed within response variable due to unbalanced data; the maximum SE is reported. } \\
\text { "Pairwise comparisons within columns and celosia species by least significant difference at } \alpha=0.05 \text {. Means followed } \\
\text { by the same letter are not significantly different. }\end{array}$} \\
\hline
\end{tabular}

in the semiarid southwestern United States.

There are limited data on yield and quality of field-grown cut flowers. We have reported field production data for two species of globe amaranth and two species of celosia in relation to yield periodicity, yield longevity, and response to various planting densities that should aid in crop selection, crop scheduling, and determination of planting design to suit regional needs. Although much higher field planting densities of common globe amaranth and cockscomb celosia have been reported (Jhon and Paul, 1992; Ojo, 2001), the relatively minimal effect of planting density in our study was somewhat unexpected and may relate to the high light intensity. Thus, added seedling costs associated with the highest densities may not be justified under our growing conditions. However, several exceptions should be noted. Three-row plantings increased the number of harvested spray flower stems on cockscomb and wheat celosia. A relatively large cockscomb celosia flower head size was produced when the three-row planting was combined with $20-\mathrm{cm}$ in-row spacing. On either $15-\mathrm{cm}$ or 20 - $\mathrm{cm}$ in-row spacing, longer cockscomb celosia stems were maintained later into the season and

cockscomb celosia flower midway into the season on a three-row bed, and the three-row planting prolonged spray flower stem production by cockscomb celosia if the plants were at a $15-\mathrm{cm}$ spacing within the bed. Thus, a three-row planting appears to improve field production of cockscomb celosia in our conditions.

Based on our preliminary findings, further research could integrate field crop scheduling with yield optimization, water conservation, and production cost and return analysis of these species. The long growing season of southern New Mexico could support spring and fall plantings of cockscomb celosia and overcome the apparent lack of flower initiation we experienced under long days. The low fall yield of 'Strawberry Fields' globe amaranth may not justify the added costs of irrigation, cultivation, harvesting, and processing. Financial analysis should compare relatively high annual yield per area and increased harvest labor for the lighter but numerous stems of the two globe amaranth species with the relatively low annual yield per area and less harvest labor for the heavier, less numerous stems of the two celosia species. This study was completed under non-limiting water conditions, but potential exists to irrigate in amounts below non-stress water levels, at least for cockscomb celosia (Fawusi et al., 1984). Further study could resolve these uncertainties for desert growing conditions.

\section{Literature cited}

Armitage, A.M. 1993. Specialty cut flowers. Varsity Press, Portland, OR.

Carter, C.T., C.M. Grieve, J.A. Poss, and D.L. Suarez. 2005. Production and ion uptake of Celosia argentea irrigated with saline wastewaters. Scientia Hort. 106: 381-394.

Dole, J.M. and H.F. Wilkins. 2005. Floriculture principles and species. 2nd ed. Prentice Hall, Upper Saddle River, NJ.

Fawusi, M.O.A., D.P. Ormrod, and A.M. Eastham. 1984. Response to water stress of Celosia argentea and Corchorus olitorius in controlled environments. Scientia Hort. 22:163-171.

Gavlak, R.G., D.A. Horneck, and R.O. Miller. 1994. Plant, soil, and water reference methods for the western region. Western Coordinating Committee, Western Reg. Ext. Publ. 125. Western Rural Dev. Ctr., Corvalis, OR.
Jhon, A.Q. and T.M. Paul. 1992. Effect of spacing, nitrogen, and pinching on globe amaranth (Gomphrena globosa). Indian J. Agron. 37:627-628.

JongGoo, K. and M.W. van Iersel. 2002. Nutrient solution concentration affects growth of subirrigated bedding plants. J. Plant Nutr. 25:387-403.

New Mexico State University. 2009. New Mexico Climate Center. 6 Aug. 2009. $<$ http://weather.nmsu.edu>.

Ojo, D.O. 2001. Density and cutting height affect production of celosia (Celosia argentea L.) in the humid tropics. J. Veg. Crop Production 7:45-55.

Picchioni, G.A., C.J. Graham, and A.L. and macroelement uptake of field-grown Asimina triloba (pawpaw) irrigated with low-saline, sodic water. HortScience 39: 1104-1109.

Porat, R., E. Shlomo, and A.H. Halevy. 1995. Horticultural techniques to improve Celosia plumosa growth for cut flowers. Scientia Hort. 63:209-214.

Stevens, A.B. 1998. Field grown cut flowers: A practical guide and sourcebook. Avatar's World, Edgerton, WI.

Still, S.M. 1994. Manual of herbaceous paign, IL. Ulery. 2004. Gypsum effect on growth ornamental plants, 4th ed. Stipes, Cham- 